\title{
Studies on maturation, spawning and hatching wild of shrimp penaeus monodon fabrics, 1798 collected from east coast of india
}

\begin{abstract}
In overall 568 unablated Penaeus monodon brood stock were collected from the different region of south east coast of India for the study of maturation, spawning and hatching performances. To stimulate ovarian maturation and spawning of P.monodon through eye stalk ablation and controller animal aspects of the atmosphere were taken into attention. The number of eggs depends on the weight of female that varied from 2,72,000 to 4,57,000 having the bodyweight of $100 \mathrm{gm}$ to $150 \mathrm{gm}$ were the average number of eggs was $4,05,000$. The $52.5 \%$ of eggs were fertilized and $85 \%$ of them produced nauplii.
\end{abstract}

Keywords: Maturation, Spawning, Hatching, Penaeus monodon,South east coast of India, Brood stock
Volume 2 Issue 5 - 2015

\author{
Kannan DD,' Thirunavukkarasu $P^{2}$ Ashwini \\ kumar, ${ }^{2}$ Shettu $N^{\prime}$ \\ 'PG \& Research Department of Zoology, Pachaiyappa \\ ${ }^{2}$ Centre of Advanced Study in Marine Biology, Faculty of Marine \\ Sciences, Indi
}

Correspondence: Kannan D, PG \& Research Department of Zoology, Pachaiyappa, Tel 9I+7299247299,

Email pdkannan1970@gmail.com

Received: June 28, 2015 | Published: September 08, 2015

\section{Introduction}

Marine shrimp farming is the most important aquaculture sector in the world and as reported by MPEDA in 2011 about $75 \%$ of farmed shrimp is produced in Asia where in China, India, Malaysia and Indonesia. In penaeid prawn hatcheries, efforts to ensure the reproductive success of the prawn brood stock have focused almost entirely on the maturation stage of female spawners. The Successful and sustainability of any aquaculture system, whether saline water or fresh water, depends on the availability of quality brooders and seeds in the time. Shrimp culture productions are a vital measure in the fisheries division in India.

In penaeid prawn hatcheries, efforts to ensure the reproductive success of the prawn brood stock have focused almost entirely on the maturation stage of female spawners. ${ }^{1}$ A large number of shrimp hatcheries have been established in India. All the hatcheries are using wild spawners and fully mature shrimps. Availability of such shrimps is very limited, seasonal and only at a few centers such as Nagapattinam, Palayar, Cuddalore, Chennai in Tamil Nadu, Visakhapatnam in Andrapradesh and Paradeep in Odisha. Hatcheries operate at less than $60 \%$ of their capacity due to non-availability of spawners/Brood stocks. Further, the shrimp suffer mortality during the transportation at sea to on land. Quality gets to affected with infections due to handling and transportation stress. Unhealthy competition to hike up the prices The black tiger shrimp,Penaeus monodon is a major shrimp amid peaneids in addition to which is extreme appropriate for aquaculture in India. For that reason, P.monodon seed is a numerous demand and it is approximately 12 billion in each year. By the side of existing shrimp hatcheries able to produce 10 to 12 billion post larvae (FAO205)

Worldwide expansions of shrimp farming over the last two decades are attributed mostly to the accomplishment in the establishment of great lead nauplli by way of meticulous maturation and reproduction. ${ }^{2}$ Besides the technology obtained in south Asian countries. Entire commercial hatcheries and research amenities are universal by eyestalk ablation procedure is broadly used by the stimulation of maturation. ${ }^{3-6}$ The obtain ability of brood stock ofP.monodon mostly governed by the caught of the wild spawns from the Indian coastline.
In appropriately the numbers of spawners has been declined year by year then continuously the rate of gravid stage of female has been augmented every year. As a result, to certify a constant source of post larval P.monodon, the stimulate maturation and spawning in confinement are very essential.

The meticulous maturation and spawning of sustainable eggs are appropriate production of high heath nauplli has been a remarkable aim for the shrimp aquaculture manufacturing in several years. For periods researchers have worked to unpick the physiological processes involved in ovarian development, mating and spawning, so far important breakdown in our information remain. Regularly successful maturation has been achieved with diets of fresh frozen marine organisms, live polychaetes worms, with or without dry feed supplements. The number of environmental variables has been shown to significantly affect the reproduction of penaeid shrimp in captivity, acting alone or synergistically. These include: duration of light period, light power, light colour, sound, tank background color, tank dimensions, interchange of water, water purifications system, temperature and various water quality parameters (Table 1). The consequence of the current study will be supportive to improve an orientation record on the spawners stage growth by the eyestalk ablation and hatching technique of P.monodon composed from the offshore water of Indian coastline.

Table I Levels water quality parameters in P. monodonMaturation

\begin{tabular}{ll}
\hline Parameters & Range \\
\hline Temperature & $27.5-28.5^{\circ} \mathrm{C}$ \\
Salinity & $33 \mathrm{ppt}$ \\
Total ammonia & $0-0.5$ \\
Nitrate & $0-0.3$ \\
$\mathrm{pH}$ & $7.8-8.2$ \\
\hline
\end{tabular}

\section{Materials and methods}

The experiment was carried out in September 2013 to November 2013 at M/s Krishna Hatcheries, Chennai, where suitable experimental facilities aimed the scholarship of hatchery operation and management are obtainable. 


\section{Brood stock collection}

The brood stocks were composed from the various fishing landing centres of Indian coastline using high mechanised boat. The full developed male and female were packed at 2 no's of individual polythene bag with apt oxygenated by shielded vehicle towards to the hatchery (Figure $1 \& 2$ ). If done overland, only transport during the cooler night-time periods. Only transport brood stock shrimp that are in inter-molt stage as animals that molt in transport will die and may kill the other shrimp packed with them. Place rubber tubes over the rostrum of the shrimp to avoid puncturing the plastic bags (Table 2).

Table 2 Feeding program for Brood stock

\begin{tabular}{lll}
\hline Feed Time & $\%$ of Feed & Combination \\
\hline 07.00am & I5 & Feed with Polychaetes \\
II.00 am. & 10 & Feed with Squids \\
$16.00 \mathrm{am}$ & 10 & Feed with Oyster \\
$22.00 \mathrm{am}$ & 60 & Feed with Polychaetes \\
02.00am & 5 & Feed with INVE Semi-moisture pellet feed. \\
\hline
\end{tabular}
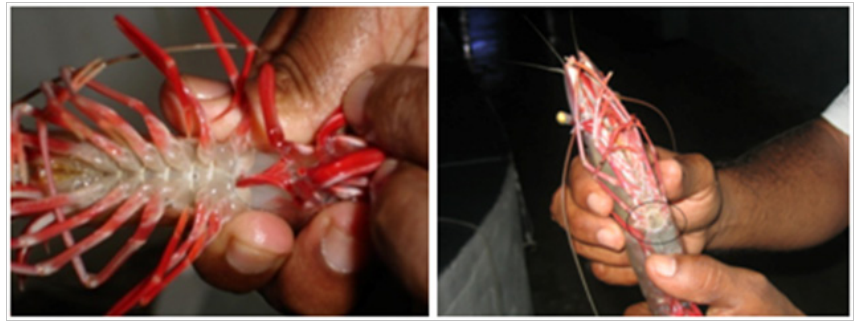

Figure I Healthy male brood stock with spermatophores; Healthy Female brood stock with attachment of Spermatophores.
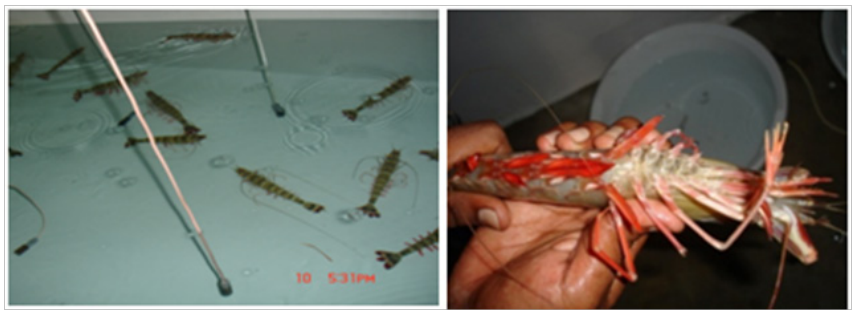

Figure 2 Brood stocks in the maturation tanks; Spermatophore in Female Thelycum.

\section{Experimental design}

Respectively every maturation tank is being painted in black and a central hole. ${ }^{3,4}$ The drained sea water was recirculating through bio filters, cartridge filter, activated carbon filter and protein skimmers. Recirculation rate was used to $1200 \%$ of each tank volume per day. In adding, of 5-10\% fresh seawater was filled to recirculation system to elude high nitrate concentrations. Fluorescent bulbs $80 \mathrm{w}$ were hung $0.5 \mathrm{~m}$ overhead each tank to acquire the favourite photoperiod $14 \mathrm{~h}$ light and 10 dark. Molting, maturation and spawning of every female were examined and noted daily. For this determination, females were noticeable by number tagging nearby the eye stalk. ${ }^{3-5}$

\section{Evaluated water quality parameters}

At maturation, spawning and hatching the water value was conserved the salinity at $28-33 \mathrm{ppt}$, temperature is $28{ }^{\circ} \mathrm{C}$ and $\mathrm{pH}$ is 7.8-8.2, Salinity, temperature, dissolved oxygen and ammonia level of maturation tank were observed daily and $\mathrm{pH}$ and nitrite were monitored weekly. Salinity was dignified with a refractometer, Oxygen and temperature by an YSI hand oxygen meter and $\mathrm{pH}$, ammonia, nitrate and nitrite by Merck test kits. The supplied seawater was filtered by using slow sand filter, Rapid sand filter, cartridge filter and UV to remove the bacteria and other undesirable particles. The water level maintained in the maturation tank ant it kept at $50 \mathrm{~cm}$ with constant recirculation systems. In the maturation tanks constant aeration was providing to unavoidable of the stress of the brood stocks (Table 1).

\section{Fresh food maturation diets}

About $20 \%$ of biomass was served fed to the shrimp and components of squid, polychaetes worms, Tuna fish eggs and oyster etc., at the morning $5.30 \mathrm{am}$ and the evening $5.00 \mathrm{pm}$, all the left over fed, faecal matter and moulted shell were removed by siphoning at the maturation tanks.

\section{Eye stalk ablation}

In the experimental to ablation, the males and females were engaged in two isolated brood stock tanks holding 500L seawater. The males were shifted to the maturation tank subsequently treating by antibiotic $10 \mathrm{ppm}$ used for one hour. Each female segregated from the allotment tank of females was taken and it one clench it one hand by head in front of away from the body and checked both eyes intended for any damaged. Eye was ablated at the injured one. Several techniques have been used for ablating shrimp including slitting the eye ball and squeezing out the contents while pinching the eye stalk, simple cutting of the eye stalk, ligation by tying a thread around the base of the eye stalk and burning through the base of the eye stalk with an surgical forceps. ${ }^{4,7-9}$ Ablation of females during late premoult or early post moult stages has been associated with high mortality rates. ${ }^{2,10}$ Ablation was agreed out unilaterally with a head surgical forceps. ${ }^{11}$ This seems to be finest technique to hold the haemolymph from penetrating from the wound. The body weight of the ablated females ranges from 100-150 gm. After ablation females were kept in 1000L tanks encompassing antibiotic treatment 10ppm oxytetracycline and $10 \mathrm{ppm}$ ciprofloxacin. After one hour of ablated and then transferred to the maturation tanks (Figure 3 ). The maturation tank capacity 10 Ton and the 60 nos of stocked by the sex ration of male and female 1:1 Most maturation systems for closed thelycum penaeids utilize a one male to female ratio. ${ }^{4,5,12,13}$

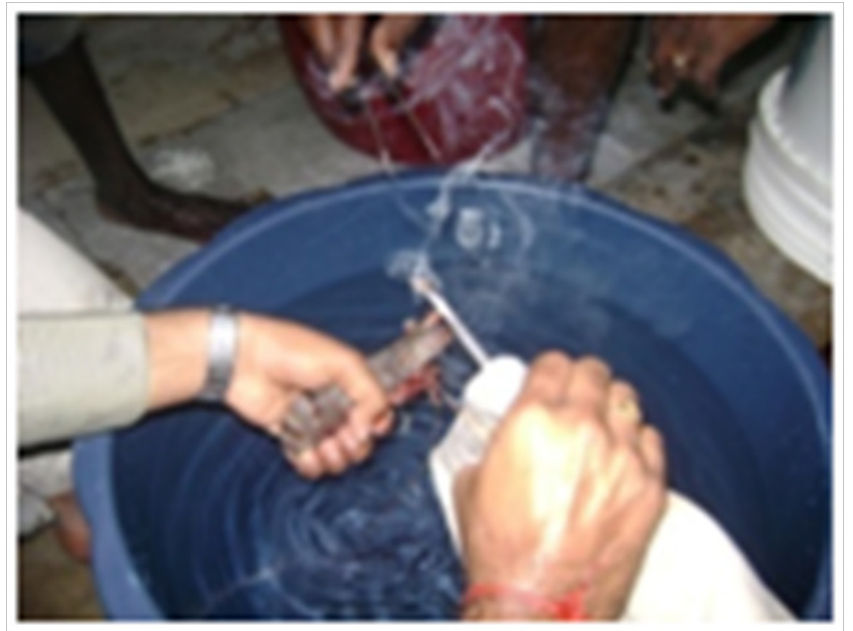

Figure 3 Eye stalk ablation.

\section{Spawners sourcing}

In maturation systems, sourcing requires selection and removal of ripe mated females to separate spawning tanks. Sourcing is regularly carried out daily. The grading of maturation was observed immensely 
by examining the size of the developed ovaries complete the dorsal exoskeleton on everyday source in the evening at $5.30 \mathrm{pm}$. By showing light in contradiction of the side stomach with a water-resistant hand light, mainly in the area behind the cephalothoraxes on P.setiferus, Cummings $^{14}$ on P.duorarum ${ }^{15}$ on P.merguinesis. They describe five development stages: Un developed or immature, developing or early maturing, yellow or late maturing, ripe or mature and spent. Ovarian development can be characterized via external observation of the size and colour of the ovaries based on the work of King. ${ }^{16}$ The selected spawners were dipped about one minute in 100ppm formalin. Subsequently formalin bath the female was washed by the sea water and kept in the spawning tanks (Figure 4).
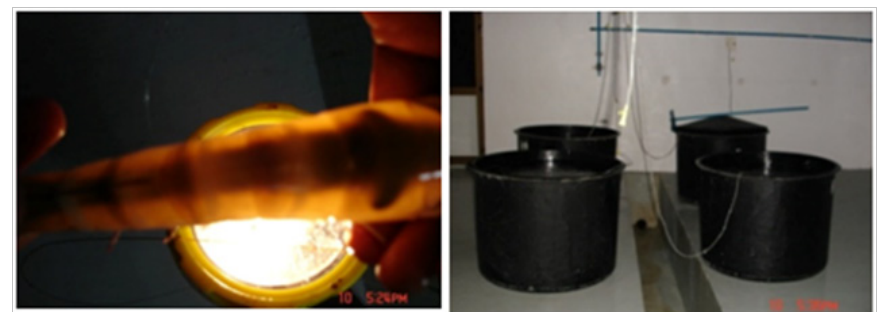

Figure 4 Fourth stage spawner; Hatching Tanks.

\section{Spawning and hatching}

At every spawning tank 500 lit a spawner was kept and additional treated with $10 \mathrm{ppm}$ EDTA and $0.1 \mathrm{ppm}$ treflan. EDTA is added to spawning tanks in many systems at 3 to $10 \mathrm{ppm}$, to reduce toxicities of heavy metals. ${ }^{17}$ The fungicides Treflan can be used at $0.1 \mathrm{ppm}$ to prevent fungus infections during larval rearing. ${ }^{18}$ Afterwards spawning the disbursed females were isolated from the tanks by a scopnet. The spawning tank water was siphoned by a hose and the water were passed through a 350 micron hand net in which the eggs pass through water as well as retains faecal matter and the eggs collected on a 100 micron net in a harvest bucket. The harvested eggs were washed carefully by running sea water at least for 5 minutes and the eggs were dipped with $100 \mathrm{ppm}$ formalin for 30 seconds and $50 \mathrm{ppm}$ iodine for 60 seconds and yet again washed meticulously by running sea water for 5 minutes before transferred into the hatching tanks $500 \mathrm{~L}$ for advance $36 \mathrm{~h}$ to define the hatching rate. The quantity of eggs and the ratio of the fertilized eggs were assessed by using the formula. The hatching rate was examined by using the formula: $\mathrm{H} \%=\mathrm{Y} / \mathrm{X} * 100 \%$

$\mathrm{H}=$ hatching rate $=$ total number of nauplii and $\mathrm{X}=$ total number of eggs. ${ }^{11}$

\section{Assessment of reproductive performance:}

Reproductive performance was evaluated over a range of regular parameters measured at the individual succeeding stage of the maturation as well as spawning development. Amounts of fecundity, fertility, hatching and nauplli production were calculated for the each female.

\section{Results}

\section{Water quality}

Regularly the water temperature range of $27-28.5^{\circ} \mathrm{C}$ and the Dissolved oxygen ranged between 5 and $6 \mathrm{mg} / 1$, total ammonia was under $0-0.5 \mathrm{mg} / \mathrm{l}$ even though recorded nitrite values were $0-0.3 \mathrm{mg} / \mathrm{l}$, salinity was sustained $33 \mathrm{ppt}$ and $\mathrm{pH}$ ranges between 7.8-8.2 during the entire experimental of maturation tank.

\section{Reproductive performance}

An important aspect of present study is on the influence of brood stock fecundity of eggs under spawning condition on the maturation of shrimps under captivity. This study is aimed in filling up the gap in aquaculture industry. Egg production is a purpose of the quantity of eggs per spawners. As the size of females increased from 100-104 $\mathrm{g}$ to $146-150 \mathrm{~g}$ in (Table 3), the mean number of eggs per spawning increased from 2, 71,000 to 4 and 56,000. The larger females would be expected to produce more eggs per spawning. The relationship between eggs per spawning and the spawning number differed between body weights of brood stocks. The fecundity rate was increased from 115-139 g onwards. The percentage of fertility of female brood stock varied from $58 \%$ to $89 \%$ respectively as well as the percentage of hatching ranges from $67 \%$ to $96 \%$. Total nauplii production varied strongly among females, ranging from 1.05 Lakhs to 3.89 Lakhs nauplii per female.

Table 3 Relationship between body weight (gm) and No. of eggs of P.monodon

\begin{tabular}{llll}
\hline $\begin{array}{l}\text { Body Wt } \\
(\mathbf{G m})\end{array}$ & No. of Spawners & Total No. of Eggs & $\begin{array}{l}\text { Average No. of } \\
\text { Eggs }\end{array}$ \\
\hline $100-104$ & 67 & 182.2 & $2.7 \mid$ \\
$105-109$ & 72 & 198.7 & 2.75 \\
$110-114$ & 84 & 249.4 & 2.96 \\
$115-119$ & 92 & 296.2 & 3.21 \\
$120-125$ & 112 & 424.4 & 3.78 \\
$126-130$ & 77 & 351.8 & 4.56 \\
$131-135$ & 42 & 181.44 & 4.32 \\
$136-140$ & 12 & 49.4 & 4.11 \\
$14 \mid-145$ & 7 & 25.9 & 3.7 \\
$146-150$ & 3 & 11.7 & 3.9 \\
\hline
\end{tabular}

\section{Discussion}

The overall 414 single brood stock obtainable of 568 females were answered to spawn absolutely. First colour of the ovary was whitish which revolved slowly greenish to dark olive green on the spawning day. Ovarian development can be characterized via external observation of the size and color of the ovaries based on the work of king (1948) on P.setiferus, Cummings ${ }^{14}$ on P.duorarum and Tuma $1967^{15}$ on P.merguinesis. They describe five developmental stages: undeveloped or immature, developing or early maturing, yellow or late maturing, ripe or mature and spent. According to Aquacop ${ }^{10}$ spawning was witnessed to take place between $10.00 \mathrm{pm}$ to $4.00 \mathrm{am}$ and Das et al. ${ }^{19}$ revealed that the spawning took place between $9.00 \mathrm{pm}$ to midnight and midnight to 5.00 am correspondingly. In this study, entire spawning practice was accomplished within 2-5 minutes where Das et al. ${ }^{19}$ stated 5-10 minutes. During maturation periods were feed $20 \%$ of the total biomass four times daily at $6.00 \mathrm{am}, 12.00 \mathrm{pm} .5 .30$ pm and 10.00 pm. ${ }^{11,20,21}$

In this study, the documented from 5 to 30 days after the eyestalk ablation for the time condition of ovarian maturation. The first spawning of P.monodon was found on 5th day where 4 females were observed completely established ovaries. However, Beard \& wickens ${ }^{21}$ while working on P.monodon breeding stated that maturation could be attained within 5 to 11 days after eye stalk ablation. The number of spawned eggs ranges from 2, 72000 to 4, 57000 nearly. The maximum quantity 4, 56000 of spawned eggs was witnessed female of 127 gm body weight as well as the lowermost quantity of 2, 71000 was perceived from the female of $102 \mathrm{gm}$ body weight The ratio eggs to be subject the quantity of spawned eggs and the range was witnessed from $35 \%$ to $70 \%$ Aquacop $^{10}$ revealed that the proportion of fertilized 
eggs range from $40 \%$ to $100 \%$. Unfertilized eggs, fertilized eggs with full and incomplete progress three types were seen. Subsequently spawning, the nauplii existed out the day time, between $1.00 \mathrm{pm}$ to $3.00 \mathrm{pm}$ after spawned, 36 hours the nauplli reached 6th sub stages as well as the ratio of hatched nauplii ranges from 70 to $100 \%$ and the mean was $85 \%$. The percentage of hatching range was described 88 Das et al. ${ }^{19}$ The present study which indications a close relation of $63 \%$.

Traditionally, shrimp hatchery owners have depend on wild caught brood stock to provide seed supply to the shrimp farmer for their ponds and there is a observation that nauplii and post larvae derived from these brood stocks are superior in quality to those produced from captive-reared shrimp. ${ }^{2}$ In 1992 , Kawahigashi reported that $80 \%$ of the maturation technician surveyed from western hemisphere hatcheries used wild caught brood stock, whereas $20 \%$ used a combination of wild-caught and pond reared brood stock. However, because of the devastating impacts of viral diseases and an unpredictable supply of wild brood stock, there has been a growing need to develop technologies for the captive rearing, maturation and reproduction of shrimps. Results from this survey also indicated an increasing interest in bio security, as $74 \%$ of the respondents claimed to use bio secure strategies such as footbaths, viral screening, disinfecting influent water and quarantine procedures. Several other reviews of the shrimp maturation and reproduction literature have been written Muthu \& Laxmianarayanana, ${ }^{4}$ Primavera, ${ }^{12}$ Chamberlain ${ }^{22}$ and these provide a base for the present effort. In the female penaeid shrimp with ripe ovaries caught from sea, the number and or hatching rate of the eggs spawned were greater than those from ablated females matured in tanks after catching from sea. ${ }^{5,23}$

The nauplii production from ablated, wild-caught and pondreared L.vannamei that mated naturally ranged from 47000 to 106400 nauplii spawn. ${ }^{24}$ In another study reported with non-ablated according to Medina-Reyna et al..$^{25}$ L.vannamei, revealed that average nauplii production from naturally copulated wild females varies from 83000 to 189000 nauplii per spawn. In an investigate carried out by Uddin et al. ${ }^{26}$ an additional food diet containing crab, squid, clam and beef liver was served to female wild brood stock black tiger shrimp 65 $120 \mathrm{gms}^{2,3,7}$ as well as the results showed that a fecundity of $1,70,300$ $(70,000-3,75,000)$ eggs per offspring with mean fertilization range of 77. $26 \%$ and the hatching range of $83.28 \%$. Coman et al. ${ }^{27}$ studied that the wild balck tiger brood stock shrimp with a mean weight of $90 \mathrm{~g}$ provided a fecundity of $1,40,340$ eggs per spawning with a mean hatching frequency of $36.4 \%$ when served a diet comprising of $30 \%$ squid, $15 \%$ bivalves, $5 \%$ polychaete and $50 \%$ pellet. Since the early 80's nauplii production of F.paulensis in Brazil has been based on the capture of wild brood stocks in coastal waters off Santa Catarina. ${ }^{28-30} \mathrm{It}$ is well known that deep sea $60-100 \mathrm{M}$ caught F.paulensis brood stock existing a greater egg and nauplii production than the animals from cultured pond, ${ }^{29,30,31}$ but their costs and unpredictable supply are the major constraints to nauplii production. However due to low costs, breeders may also be captured in shallow 5-10 M waters. While the propagative enactment of these brood stocks may be suitable ${ }^{32}$ a marked decrease in egg quality and nauplii viability was observed. ${ }^{33}$

When ablated females have been compared to non-ablated controls, the size of the spawns have been reported to be larger, ${ }^{34}$ smaller ${ }^{8,35}$ and not different ${ }^{35,36}$ or not different. ${ }^{36}$ Hatch success has been reported to be lower or not different. ${ }^{8,34}$ Some others reported deterioration in spawn quality from ablated females over time..$^{21,35,37}$ Evidence of abnormal ovarian development in a crab ablated during the prebreeding season has been reported. ${ }^{38}$ Vogt et al..$^{39}$ observed a single P.monodon female with oocytes in all stages of development, however, other studies found no differences in fine structure. ${ }^{40}$ Bray \& Lawrence ${ }^{41}$ recounts observations of poor ovary colour, morphological deformities, retarded larval development, lower larval survival, increased disease susceptibility and larger size distributions for larvae from captive, eyestalk ablated stocks as compared to those from wild gravid females.

According to Emmerson, ${ }^{35}$ Hiller $^{42}$ noted a higher range of spawning of 2, 57,650 to 5, 50,330 eggs per spawn from wild ablated P.monodon and 60,000 to 7,47, 5000 eggs from non-ablated females. The wide-ranging in egg numbers achieved possibly owing to deviations in weight of females 50-200 $\mathrm{g}$ and the presence of eggs in calculations as of together partial and complete spawning Alikunhi et al., ${ }^{43}$ Muthu \& Laxminarayana. ${ }^{44}$ According to Ramesh ${ }^{45}$ the highest rate, $90 \%$ hatching was noted in wild unilateral eye stalk ablated shrimps fed by way of crab and polychaete and lowest hatching rate, $69 \%$ was found in wild unilateral ablated shrimps fed through oyster and beef liver (Table 4).

Table 4 Relationship between body weight (gm), No. of eggs. Fertility, hatching and Nauplii production of wild brood stock P.monodon

\begin{tabular}{lllll}
\hline $\begin{array}{l}\text { Body } \\
\text { Weight }\end{array}$ & $\begin{array}{l}\text { Avg. No. of } \\
\text { Eggs }\end{array}$ & $\begin{array}{l}\text { Avg. No. of } \\
\text { Fert. }\end{array}$ & $\begin{array}{l}\text { Avg. No. of } \\
\text { Hatch }\end{array}$ & $\begin{array}{l}\text { Avg. No. of } \\
\text { Nauplii }\end{array}$ \\
\hline $100-104$ & $2.71(\times 1000)$ & $58 \%$ & $67 \%$ & $1.05(\times 1000)$ \\
$105-109$ & 2.75 & $63 \%$ & $70 \%$ & 1.21 \\
$110-114$ & 2.96 & $71 \%$ & $74 \%$ & 1.55 \\
$115-119$ & 3.21 & $82 \%$ & $78 \%$ & 2.05 \\
$120-124$ & 3.78 & $85 \%$ & $89 \%$ & 2.85 \\
$125-129$ & 4.56 & $89 \%$ & $96 \%$ & 3.89 \\
$130-134$ & 4.32 & $86 \%$ & $90 \%$ & 3.3 \\
$135-139$ & 4.11 & $80 \%$ & $85 \%$ & 2.79 \\
$140-145$ & 3.7 & $77 \%$ & $81 \%$ & 2.30 \\
$146-150$ & 3.9 & $76 \%$ & $72 \%$ & 2.13 \\
\hline
\end{tabular}

Improvement of quality of water used in maturation tanks, spawning and hatching tanks through UV radiation found to reduce the levels of specific pathogenic microorganisms in the incoming sea water may be of help in the overall improvement of the reproductive performance. Efforts should also be made to investigate the male shrimps, which will be of help in enhancing the fertilization and hatching rates. Poor water parameters also affect reproductive quality. ${ }^{41}$ Nevertheless, the water quality for all treatments was considered ideal for the species, ${ }^{46}$ with temperature between $24.5{ }^{\circ} \mathrm{C}$ to $29{ }^{\circ} \mathrm{C}$ and salinity of 33 to 35 ppt. Thus, food probably was important factor for aggrieved the ovarian reabsorption reported in the results of the present study.

\section{Acknowledgments}

None.

\section{Conflicts of interest}

None.

\section{References}

1. Alfaro J. Reproductive quality evaluation of male Penaeus stylirostris from a grow-out pond. J World Aquac Soc. 1993;24(1):6-11.

2. Browdy CL. Recent developments in penaeid broodstock and seed production technologies; improving the outlook for superior captive stocks. Aquaculture. 1998;164(1-4):3-21.

3. Caillouet CW. Ovarian maturation by eyestalk ablation in pink shrimp Penaeus duorarumBurkenroad. Proceeding of Annual Workshop. 


\section{World Mariculture Society. 1973;3(1-4):205-225.}

4. Muthu MS, Lakshmi A, Laxinarayana. Induced maturation of penaeid prawns-a review. Proceedings of the Symposium on Coastal Aquaculture. 1982;1:16-27.

5. Lumare F. Reproduction of Penaeus Kerrathurus using eyestalk ablation. Aquaculture. 1979;18(3):203-214.

6. Aktas M, Kumlu M. Gonadal maturation and spawning of Penaeus semisulcatus. Tur J Biogy. 1999;23:61-66.

7. Kelemec JA, Smith IR. Induced ovarian development and spawning of Penaeus plebejus in a recirculating laboratory tank after unilateral eyestalk enucleation. Aquaculture. 1980;21(1):55-62.

8. Browdy CL, Samocha TM. The effect of eyestalk ablation on spawning, moulting and mating of Penaeus semisulcatus (De Haan). Aquaculture. 1985;49(1):19-29.

9. Makinouchi S, Honculda-Primavera. Maturation and spawning of Penaeus indicususing different ablation methods. Aquaculture. 1987;62(1):73-81.

10. Aquacop C. Reared bloodstock of Penaeus monodonSymp. Coastal Aquaculture. 1982;1:55-62.

11. Chen CA. Preliminary report on the gonadal development and induced breeding of penaeus monodon Fabricus. MS Thesis. Institute of Oceanography, National University Taipei, Taiwan. 1979.

12. Primaveras JH. A review of maturation and reproduction in closed thelycum penaeids. In: Taki et al. (Eds.), Proceedings of the first International Conference on the Culture of Penaeid /Shrimps. Aquaculture Department SEAFDEC, IIoilo, Philippines. 1985;p.47-64.

13. Emmerson WD, Andrews B. The effect of stocking density on the growth and development and survival of Penaeus indicus(Milne Edwards) larvae. Aquaculture. 1983;23(1-4):45-47.

14. Cummings WC. Maturation and spawning of the pink shrimp Penaeus duorarum Burkenroad. Transactions of the American Fisheries Society. 1961;90(4):462-468.

15. Tuma DJ. A description of the primary and secondary sexual characters in the banana prawn Penaeus merguinesis de Man (Crustacea ; Decapoda; peaneidae ). Australian Journal of Marine and Freshwater Research. 1967;18(1):73-78.

16. King JE. A study of the reproductive organs of the common marine shrimp, Penaeus setiferus (Linnaeus). Biol Bull. 1948;94(3):244-262.

17. Licop MSR. Sodium-EDTA effects on survival and metamorphosis of Penaeus monodonlarvae. Aquaculture. 1988;74(3-4):239-247.

18. Wyban JA, Sweeney JN. The Oceanic Institute Shrimp Manual: Intensive Shrimp Production Technology. The Oceanic Institute, Waimanalo, Hawaii, USA. 1991

19. Das NG, Sarwar MM, Parvez MM. Water quality management during gonadal maturation of penaeus monodon fabricus in a commercial hatchery at Coxs Bazar. J Zool. 1997;25:65-70.

20. Santiago AC. Successful spawning of cultured penaeus monodonFabricus after eyestalk ablation. Aquaculture. 1977;11(3):185-196.

21. Beard TW, Wickins JF. Breeding of Penaeus monodon, Fabricus in laboratory recirculation system. Aquaculture. 1980;20(2):79-89.

22. Chamberlain GW. Stepwise investigation of environmental and nutritional requirements for reproduction of penaeid shrimp. Doctoral thesis. Texas A\&M University, College Station, Texas, USA. 1988;pp.228.

23. Lin MN, Ting YY. Observation of poor hatching in the unilateralablated females of penaeus monodonFabricus. Bull Japan Soc Sci Fish 1986;52(2):355
24. Palacios E, Perez Rostro CI, Ramı'rez JL, et al. Reproductive exhaustion in shrimp (Penaeus vannamei) reflected in larval biochemical composition, survival, and growth. Aquaculture. 1999;171(3-4):309321

25. Medina-Reyna CE, Beltrán-González MH, Salinas-Orta HT. Nauplii production of white shrimp, Litopenaeus vannamei (Decapoda: Penaeidae), on board of commercial trawlers. Rev Biol Trop. 1999;47(4):913-916.

26. Uddin SA, Das NG, Kamal AHM. Maturation and spawning of penaeid shrimp Penaeus monodonFabricus collected from off shore water of the Bay of Bengal. Int J Agric Biol. 2005;7(6):925-927.

27. Coman GJ, Arnold SJ, Peixoto S, et al. Reproductive performance of reciprocally crossed wild caught and tank reared Penaeus monodonbrood stock. Aquaculture. 2006;252(2-4):372-384.

28. Marchiori MA, Boff MH. Induced maturation, spawning and larvae culture of the pink shrimp Penaeus paulensis Pérez-Farfante, 1967. Memorias Asociación Latinoamericana Acuicultura. 1983;5:331-337.

29. Beltrame E, Andreatta ER. Maturação em cativeiro do camarãorosa, Penaeus paulensis Perez-Farfante, 1967 - Estudo sobre a origem dos reprodutores. Paper presented at Encontro Nacional de Pesca e Aqüicultura. Santos, Sao Paulo, Brazil. 1991.

30. Marchiori MA, Cavalli RO. Commercial scale maturation of Penaeus paulensis in a semi-closed recirculation system. Paper presented at: 4th Symposium on Shrimp Culture, João Pessoa, Brazil. 1993.

31. Cavalli RO, Scardua MP, Wasielesky JRW. Reproductive performance of different sized wild and pond-reared Penaeus paulensis females. $J$ World Aquac Soc. 1997;28(3):260-267.

32. Peixoto S, Wasielesky W, D`Incao F, et al. Comparison of the reproductive performance of similarly-sized wild and captive Farfantepenaeus paulensis. Journal of the World Aquaculture Society. 2003;34(1):50-56.

33. Peixoto S, Cavalli RO, D'Incao F, et al. Description of reproductive performance and ovarian maturation of wild Farfantepenaeus paulensis from shallow waters in southern Brazil. Nauplius. 2002;10:149-153.

34. Chamberlain GW, Lawrence AL. Effect of light in intensity and male and female ablation on reproduction of Penaeus stylirostris and Penaeus vannamei. J World Maricult Soc. 1981;12(2):357-372.

35. Emmerson WD. Induced maturation of prawn Penaeus indicus. Mar Ecol Prog Ser. 1980;2:121-131.

36. Primavera JH, Young T, DeLos RC. Survival, maturation, fecundity and hatching rates of unablated and ablated Penaeus indicusH.M. Edards from brackish water ponds. Quarterly Research Report/ SEAFDEC. Aquaculture Department. 1979;3(3):15-17.

37. Poernomo A, Hamami E. Induced gonad maturation, spawning and hatching of eye ablated pond grown P.monodon in recirculate water environment. In: Rogers et al. (Eds.), Proceedings of the first international conference on warm water aquaculture-crustacea: held on the Brigham Young University Hawaii campus, San Luis Obispo, California, USA. 1983;pp.412-420.

38. Anilkumar G, Adiyodi RG. Ovarian growth induced by eye stalk ablation during the prebreeding season is not normal in the crab, Paratelphusa hydrodromous (Herbst). Int J Invt Rep. 1980;2(2):195-105.

39. Vogt G, Quinto ET, Pascual FP. Interaction of the midgut gland and the ovary in vitellogenesis and consequences for the breeding success: a comparison of unablated and ablated spawners of Penaeus monodon In: DePauw N, et al. (Eds.), Aquaculture Society, Bredene, Belgium. 1989;pp.581-592.

40. Duronslet MJ, Yudin AI, Wheller RS, et al. Light and fine structural studies of natural and artificially induced egg growth of penaeid shrimp. Journal of the World Mariculture Society. 1975;6(1-4):105-122. 
41. Perez-Velazquez M, Bray WA, Lawrence AL, et al. Effect of temperature on sperm quality of captive Litopenaeus vannamei broodstock. Aquaculture. 1975;198(3-4):209-218.

42. Hiller DD. Artificial conditions influencing the maturation and spawning of sub adult Penaeus monodon(Fabricius). Aquaculture. 1984;36(12):179-184.

43. Alikunhi KH, Poernomo A, Adisukresno S, et al. Preliminary observations on induction of maturity and spawning in Penaeus monodon(Fabricius) and penaeus merguiensis de Man by eyestalk extirpation. Bull Shrimp Cult Res Cont Jepera. 1975;1(1):1-11.
44. Muthu MS, Laximinarayana. Induced maturation and spawning of Indian prawns. Indian Journal of Fisheries. 1977;24(1-2):172-180.

45. Ramesh K. Improved maturation of wild and pond-reared black tiger shrimp Penaeus monodonusing fish oil and astaxanthin feed supplements. Aquaculture. 2013;282(1-4):83-89.

46. Peixoto S, Coman GJ, Arnold SJ, et al. Histological examination of final oocyte maturation and atresia in wild and domesticated Penaeus monodonbroodstock. Aquaculture Research. 2005;36(7):666-673. 